\title{
Co-existence of Dihydrofolate Reductase (dhfr108) Gene with Plasmodium falciparum Chloroquine Resistance Transporter Gene (Pfcrt T76) in $P$. falciparum Isolates from Gezira State, Central Sudan
}

\author{
Osama A. Omer ${ }^{1}$, Ahmed EL Tahir ${ }^{2,3^{*}}$, Mohamed O Abdelwahid ${ }^{3}$, Nagla Gasmelseed ${ }^{3}$, \\ Adil Mergani ${ }^{3}$, and Nasr Eldin. M. A Elwali ${ }^{3}$ \\ ${ }^{I}$ Department of Biotechnology-Sc. \& Tech-Omdurman Islamic University, Sudan \\ ${ }^{2}$ Faculty of Medicine, King Fahad Medical City, Kingdom of Saudi Arabia \\ ${ }^{3}$ Department of Molecular Biology, Institute of Nuclear Medicine, Molecular Biology and Oncology, University of \\ Gezira, Sudan
}

\begin{abstract}
Malaria parasite multi-drug resistance poses serious health problems in tropical countries. The aim of this study was to assess the Sulfadoxine-pyrimethamine (S/P) resistance of Plasmodium falciparum parasite in central Sudan, using the molecular markers.

The genotying of $P$. falciparum parasite from forty-four patients using RFLP and PCR showed that the polymorphism of $d h f r$ gene was in codons 51, 59 and 108. In codon 51; two strains (4.5\%) were mutant type; $3(6.8 \%)$ were found as mixed infection (both mutant and wild types) and $28(63.6 \%)$ were found as wild type. One sample (2.2\%) was $d h f r 59$ mutant and $31(70.4 . \%)$ were wild type, while $14(31.8 \%)$ were $d h f r 108$ mutant; three $(6.8 \%)$ were found as mixed infection and $24(54.5 \%)$ were wild types. The Screening of dhps 540 polymorphisms of the gene revealed that $2(4.5 \%)$ were found as mixed infection, and $42(95.5 \%)$ as wild type. Fifteen samples were analyzed for Pfcrt T76, and Pfmdr-1 Y 86 for CQ resistant polymorphisms from the current study, the result showed that $33.3 \%$ were found to be mutant at $d h f r 108$ and $P f c r t 776$ genes reflecting the link between $d h f r 108$ and $P f c r t 76$ genes.
\end{abstract}

In conclusion, the polymorphism in the $d h f r$ and $d h p s$ genes in central Sudan are increasing, but less abundant compared to the neighboring countries. However, the current studies indicate the link between $\operatorname{dhfr} 108$ and Pfcrt76 genes. Therefore, further study is need for using the $\mathrm{S} / \mathrm{P}$ in areas that confirmed with chloroquine resistant strains.

Keywords: Malaria, drug resistant, dhfr, dhps, Pfcrt, Pfmdr-1, Sudan.

\section{INTRODUCTION}

Malaria is one of the most common infectious diseases in the world. There were an estimated 247 million malaria cases among 3.3 billion people at risk in 2006, causing nearly a million deaths, mostly of children under 5 years. 109 countries were endemic for malaria in 2008, 45 within the WHO African region $[1,2]$.

Plasmodium falciparum a multi-drug resistant parasite is an increasing threat to the malaria control and accelerated the morbidity and mortality rate in malaria endemic regions. Resistance to pyrimethamine has been associated with point mutations in the dihydrofolate reductase gene ( $d h f r$ - gene) and resistance to sulphadoxine with mutations in the dihydropeteroate synthase gene (dhps-gene) [3,4]. Asn 108 mutant is considered essential for pyrimethamine resistance and the degree of resistance increases with additional mutations at Ileu 51, Arg 59, or triple mutations. To date, more than 25 different combinations of $d h f r$ and dhps alleles

*Address correspondence to this author at the Faculty of Medicine, King Fahad Medical City, P.O. Box 59046 Riyadh 11525 Saudi Arabia; Tel: 00966556311460; Fax 0096612889999 E-mail: ahmedeltahirm@yahoo.com have been observed in field isolates [4]. Study in Malawi showed that patients infected with parasites carrying the dhps Gly- 437, Glu- 540 double mutant and the dhfr triple Asn 108/I leu 51-Arg 59 mutant had a specifically high relative risk of treatment failure than did those infected with parasites carrying the $d h f r$ triple mutant alone. Such a quintuple mutant (3dhfr and 2dhps mutation) was suggested as relevant molecular marker for failure of Sulfadoxinepyrimethamine (S/P) treatment of uncomplicated $P$. falciparum [4]. The presence of a single $d h f r$ mutation (Arg59) with a single dhps mutation (Glu540) might be a useful predictor of high-degree of $\mathrm{S} / \mathrm{P}$ resistance [5]. The aim of this study was to identify the frequency of dhfr 51, 59,108 and dhps 540 polymorphism in $P$. falciparum and to identify if there is any association between the different polymorphisms of P. falciparum isolates (Pfcrt T76, Pfmdr1 Y 86 and $d h f, d h p s$ ) in the Gezira state-central Sudan.

\section{MATERIALS AND METHODS}

\section{Study Site and Population}

The study was cross sectional study conducted at Marengan clinical center, Gezira state, central Sudan during 
Sept. 2002 - March 2003. One hundred and seventy six consecutive patients with symptoms or signs suggesting malaria infection were screened for the presence of malaria parasites in their peripheral blood using microscopy.

Forty-four $P$. falciparum patients $(54.5 \%$ females and $45.5 \%$ male) above two years of age were further studied to identify DHPS 540 and DHFR 108, 59, 51 polymorphisms.

\section{Ethical Approval}

The Study protocol was reviewed and passed by the ethical and scientific committees of the Institute of Nuclear Medicine (INMO), University of Gezira and the Directorate of Research, $\mathrm{MOH}$, Gezira, Sudan. Oral consent was obtained from each participant enrolled in the study.

\section{Methodology}

Blood sample from finger bricks were used to make thick and thin blood films. Blood films were stained with Giemsa and examined under the microscope.

\section{DNA Extraction and Polymerase Chain Reaction (PCR)}

DNA was extracted from filter paper blood sample using methanol extraction method [6].

\section{Outer and Nested PCR}

Outer PCR reactions were performed with $5 \mu$ of DNA prepared in $30 \mu \mathrm{l}$ volumes which contains $1 \mathrm{X}$ PCR Buffer II (Gene Amp® 10X Buffer II [100 mM Tris-HCl pH 8.3, 500 $\mathrm{mM} \mathrm{KCl}$, (Cinna Gen Inc.,Iran) $1.5 \mathrm{mM} \mathrm{MgCL2} \mathrm{(MgCl2,}$ Applied Bio system), $0.2 \mathrm{mM}$ each of the $4 \mathrm{dNTP}$ (Gene Amp ${ }^{\circledR}$ dNTPs, Applied Bio system), $1.0 \mu \mathrm{mol}$ of each sense and antisense $1 \mathrm{U}$ of AmpliTaq Gold (Applied Bio system). The cycling parameters used were: $\left[94^{\circ} \mathrm{C}\right.$ for $10 \mathrm{~min} ; 94^{\circ} \mathrm{C}$ for $1 \mathrm{~min} ; 50{ }^{\circ} \mathrm{C}$ for $2 \mathrm{~min}$ and $72{ }^{\circ} \mathrm{C}$ for $2 \mathrm{~min}$. for 40 cycles and $72{ }^{\circ} \mathrm{C}$ for $10 \mathrm{~min}$.].

The product of the outer reaction $2 \mu \mathrm{l}$ was used as a template for the second inner reaction. Forty $\mu$ of each of the primers specific for $d h f r \& d h p s$ genes were used. The cycles parameters were: $\left[94^{\circ} \mathrm{C}\right.$ for $10 \mathrm{~min} ; 94^{\circ} \mathrm{C}$ for $1 \mathrm{~min}$; $45^{\circ} \mathrm{C}$ for $1 \mathrm{~min}$ and $72{ }^{\circ} \mathrm{C}$ for $2 \mathrm{~min}$. for 35 cycles and $72{ }^{\circ} \mathrm{C}$ for $10 \mathrm{~min}$.].

The amplified DNA products were analyzed electrophoretically by size fraction on agrose gels $(1.5 \%)$ stained with ethidium bromide, and the gels were visualized under ultraviolet trans-illumination, and documented.

\section{Genotype of $d h f r 51$ and $d h f r 59$ by Restriction Fragment Length Polymorphism}

The nested PCR 113 bp products (with outer 147bp and inner $113 \mathrm{bp}$ ) were split in two tubes with $12 \mu \mathrm{l}$ PCR mix each and digested by using $0.2 \mu \mathrm{l}$ EcoR1 enzyme for dhfr mutation at position 51 and Bsrg 1 enzyme for dhfr mutation at position 59. The conditions were $2 \mu 1$ NEB $U$ buffer $10 x$ in $6 \mu \mathrm{H} 2 \mathrm{O}$ and $0,2 \mu \mathrm{l}$ of the appropriate enzyme $(10 \mathrm{U} / \mu \mathrm{l})$. The mixtures were incubated over night at $37^{\circ} \mathrm{C}$. Digested PCR products were loaded on $10 \%$ non-denaturaning polyacrylamide gel $(30 \%$ Protogel Acrylamide/Bisacrylamide,37.5:1) provided by (FMC BioProducts) and electrophoresed at $90 \mathrm{~V}$ for two hours. The digested fragments were stained in $1 \mu \mathrm{g} / \mathrm{ml}$ ethidium bromide solution for 10-15 minutes and visualized with UV light.

\section{Genotype of dhps 108 and dhps 540 [7]}

$25 \mu 1$ nested PCR 254 bp product (with outer 414 bp and inner $254 \mathrm{bp}$ ) of each sample was digested in PCR tube, by adding $3 \mu \mathrm{l}$ NEB 2 buffer 10x, 0,2 $\mu$ l Alu1 enzyme for dhfr mutation at positions 108 and Fok 1 enzyme for dhps mutation at position 540. $(10 \mathrm{U} / \mu \mathrm{l})$ the mixtures were incubated over night at $37{ }^{\circ} \mathrm{C}$. Digested PCR products were loaded on $10 \%$ non-denaturaning polyacrylamide gel $(30 \%$ Protogel [Acrylamide/Bis-acrylamide, 37.5:1]) provided by (FMC BioProducts) and electrophoresed at $90 \mathrm{~V}$ for two hours. Then the digested fragments were stained in $1 \mu \mathrm{g} / \mathrm{ml}$ ethidium bromide solution for 10-15 minutes and visualized with UV light [7]. The association between the two genes (dhfr and dhps) polymorphisms was identified using the ANOVA test.

\section{Genotype of Pfcrt and Pfmdr-1}

The mutations in the two genes Pfcrt and Pf mdr-1 have been abolished out the restriction site for Apo 1 enzyme. Digestion with this enzyme was used for typing these polymorphisms. In a total volume of $15 \mu 1,2 \mu 1$ PCR product were digested overnight at $50^{\circ} \mathrm{C}$ with $1 \mathrm{U}$ Apo I, $1.5 \mu 110 \mathrm{x}$ NE Buffer 3 (100 mM Nacl, 50 mM Tris-Hcl, $10 \mathrm{mM}$ magnesium chloride and 1mM dithiothreitol (pH $7.9 @ 25$ $\left.{ }^{\circ} \mathrm{C}\right), 0.15 \mu \mathrm{l}$ of $100 \mathrm{X}$ BSA $(200 \mu \mathrm{g} / \mathrm{ml})$ and deionized water. Using the Genomic DNA from strain 3D7 and $\mathrm{Dd}_{2}$ were Amplified and digested in the same way serving as control for complete digestion, and undigested fragment respectively. The mutations in the two genes Pfcrt and Pf mdr-1 have abolished the restriction site for Apo 1 enzyme. Digestion with this enzyme was used for typing of this polymorphism. In a total volume of $15 \mu 1,2 \mu 1$ PCR product were digested overnight at $50^{\circ} \mathrm{C}$ with $1 \mathrm{U}$ Apo I, $1.5 \mu 110 \mathrm{x}$ NE Buffer 3 (100 mM Nacl, $50 \mathrm{mM}$ Tris-Hcl,10 mM magnesium chloride and 1mM dithiothreitol (pH $7.9 @ 25$ $\left.{ }^{\circ} \mathrm{C}\right), 0.15 \mu \mathrm{l}$ of $100 \mathrm{X}$ BSA $(200 \mu \mathrm{g} / \mathrm{ml})$ and deionized water.

\section{RESULTS}

The study shows that the majority (94\%) of infections were $P$. falciparum while the remainders were mixed infection $P$. falciparum and $P$. vivax or $P$. vivax only.

Table 1 shows the occurrences of mutant genes in the study sample. Only 2/44 were dhfr 51 mutant and 3/44 were found as mixed infection; mutant and wild type in the same

Table 1. Occurrence of Resistant Gene Types in the Study Samples

\begin{tabular}{|c|c|c|c|c|}
\hline & Mutant & mixed & wild & N.D." \\
\hline DHFR108 & $14(31.8 \%)$ & $3(6.8 \%)$ & $24(54.5 \%)$ & $3(6.8 \%)$ \\
\hline DHFR59 & $1(2.25 \%)$ & 0 & $31(70.4 \%)$ & $12(27.2 \%)$ \\
\hline DHFR51 & $2(4.5 \%)$ & $3(6.8 \%)$ & $28(63.6 \%)$ & $11(25 \%)$ \\
\hline DHPS540 & 0 & $2(4.5 \%)$ & $42(95.4 \%)$ & - \\
\hline
\end{tabular}




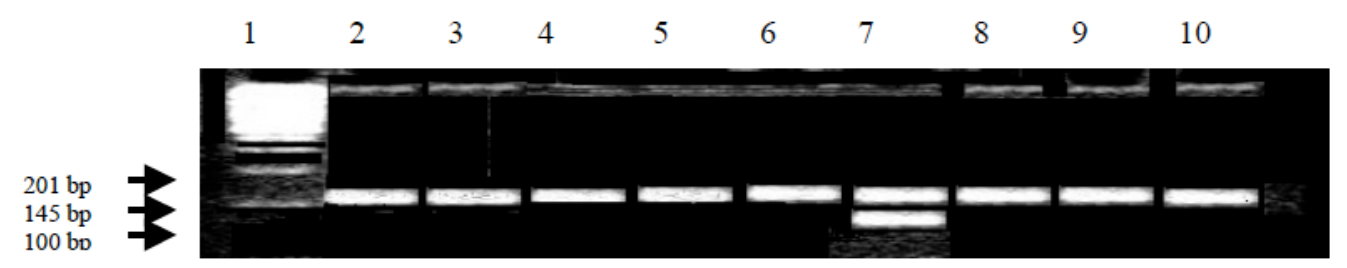

Fig. (1). PCR-RFLP screening of $P$. falciparum isolate for codon dhfr 51 polymorphism.

Lane 1 DNA marker, Lanes 2-6 and 8-10 are (uncutted full length 113 bp). PCR product (sensitive). Lane 7: 51 polymorphism (cutted by EcoR1 restriction enzyme to 78 and $35 \mathrm{bp})$.

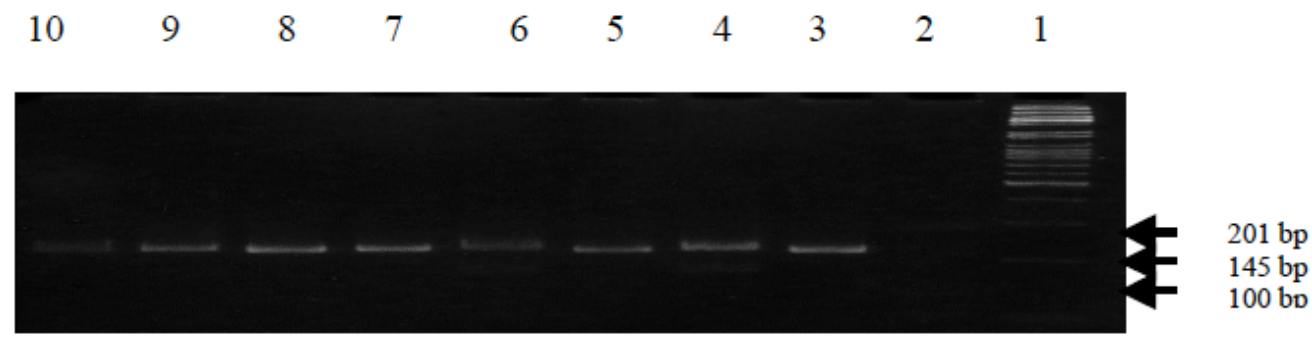

Fig. (2). PCR-RFLP screening of $P$. falciparum isolate for dhps codon 540 polymorphism.

Lane 1: DNA marker, Lane 2: digested PCR product (positive control). Lane $\mathbf{4}$ and 6; 540 polymorphism (mixed type ). Lane 3, 5 and 7- 10; 540 polymorphism (wild type).

sample, while $(63.6 \%) \mathrm{n}=26$ were undigested and considered as wild type Fig. (1). For $\operatorname{dhfr} 59$, only one sample $(2.2 \%)$ was mutant and $31(70.4$. \%) were wild type. Fourteen sample $(31.8 \%)$ were $d h f r 108$ mutant and 24 (54.5\%) were wild type, $3(6.8 \%)$ were found as mix infection represented by mutant and wild type in the same sample. The prevalence of gene mutation at position 540 indicate that $4.5 \%$ were found as mix infection represented by mutant and wild in the same sample and $95.5 \%$ was found as wild type Fig. (2). It has been found that there was significant difference between dhfr108 and dhps $540(P=0.024)$.

Fifteen samples were tested for detection of chloroquine genes Pfcrt and Pfmdr-1 polymorphisms Fig. (3). The result shows that $5 / 15(33.3 \%)$ were found with both polymorphisms for $d h f r 108$ and PfcrtT76, this result may suggest that there was association between the mutations in the dhfr 108 and Pfcrt T 76 genes.

\section{$\begin{array}{llllllllll}1 & 2 & 3 & 4 & 5 & 6 & 7 & 8 & 9 & 10\end{array}$}

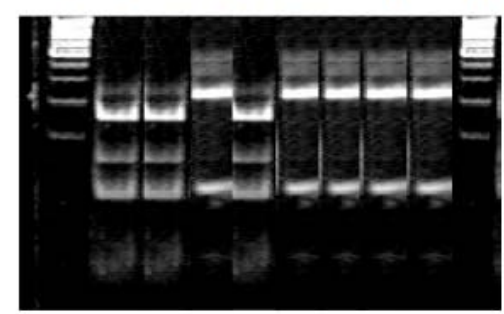

Fig. (3). PCR-RFLP screening of P. falciparum isolate for Pfcrt codon 76 polymorphism.

Lane 1 and 10: DNA markers, Lane 2: digested PCR product (positive control). Lane $\mathbf{3}$ and 5: K76 polymorphism (cutted by Apo1 restriction enzyme to145 and 64 bp). Lane 4, 6, 7, 8 and 9: T76 polymorphism (uncutted full length $209 \mathrm{pb}$ ).

Only two samples $13.3 \%$ harboured both polymorphisms for the dhfr 108 and Pfmdrl at the same time. While there was no relationship between the dhfr 51, 59 and dhps 540 with PfcrtT76 and Pfmdrl.

\section{DISCUSSION}

The prevalence of $d h f r$ and $d h p s$ polymorphisms in different $P$. falciparum isolates from central Sudan was determined by using PCR-RFLP in this study. Previous studies carried out in this country showed emergence of chloroquine and $\mathrm{S} / \mathrm{P}$ resistance [8-10]. Chloroquine resistance (CQ) in a $P$. falciparum genetic and fcrtT76, having point mutations is associated completely with $\mathrm{CQ}$ in parasite lines from Asia, Africa, and South America [11]. P. falciparum resistance to $\mathrm{S} / \mathrm{P}$ is conferred by point mutations in parasite $d h f r$ and $d h p s$ genes, which encoding the enzymes targeted by these drugs, in vitro anti-folate resistance is associated with point mutations in the $d h f r$ domain of the dhfr-thymidylate synthetase gene. Among the point mutations in the $d h f r$ gene, a Ser to Asn-108 polymorphism is considered the key mutation that confers resistance to antifolate drugs. The PCR-RFLP genotypes result from the present study revealed that target mutations conferring $\mathrm{S} / \mathrm{P}$ are $9.6 \%$ (mutant type). In addition more than $71 \%$ of the cases were characterized as (wild type). While $4.5 \%$ of the cases were found as mixed infection represented by mutant and wild in the same sample. When this result compared with other areas in Sudan it is less than that reported in Khartoum where the Pyrimethamine-Sulfadoxine efficacy was assessed before treatment and the point mutations were detected only at codons 51 and 108 of $d h f r$ and codon 436 of dhps and the frequency of dhfr 51/108 and dhps 436 mutations was $79 \%$ and $8 \%$, respectively [12]. This is probably due to the fact that there are more malaria programmes in Gezira state which gives more information about drug uses strategies and in areas where drug usage decreased, the spread of resistance has also decreased. Genetic studies show that resistance to S/P may have arisen in southern and eastern Africa on only a few occasions, so 
these resistant strains have spread extensively and rapidly [13]. S/P seems to have an unpromising future as a first line anti-malarial in Africa. Despite those results from Africa and the gametocytaemia follows treatment, S/P is still clinically effective as proved by this study and can have an impact in malaria control programs, especially in combination with other drugs like artensunate to prevent the increasing mutations and to sustain its low in vivo resistance. Interestingly we found $33.3 \%$ of the study samples were found to be mutant for $d h f r 108$ and PfcrtT76 and only $13.3 \%$ harboured mutant type for the $d h f r 108$ and Pfmdr [10].

We conclude that $\mathrm{S} / \mathrm{P}$ seems to be a suitable drug for the study area. However, the study identified the percentage of parasites carrying drug resistance polymorphism conferring resistance against $\mathrm{S} / \mathrm{P}$ and chloroquine, therefore, it might be more suitable to switch to combination therapy with artemisinin derivatives to prevent the spread of multidrug resistance.

\section{REFERENCES}

[1] WHO. World Malaria Report. Geneva, World Health Organization (WHO/HTM/GMP/2008.1) 2008; pp. 1-190.

[2] Stoppacher R, Adams SP. Malaria deaths in the United States: Case report and review of deaths, 1979-1998. J Forensic Sci 2003; 48(2): 404-8.

[3] Peterson DS, Walliker D, Wellems TE. Evidence that a point mutation in dihydrofolate reductase- thymidylate synthase confers resistance to pyrimethamine in falciparum malaria. Proc Natl Acad Sci USA 1988; 85: 9114-8.

[4] Bwijo B, Kaneko A, Takechi M, et al. High prevalence of quintuple mutant dhps / dhfr genes in P. falciparum infections seven years after introduction of sulfadoxine and pyrimethamineas first line treatment in Malawi. Acta Trop 2003; 85: 363-73.

[5] Kublin JG, Dzinjalamala FK, Kamwendo DD, et al. Molecular markers for failure of sulfadoxine/pyrimethamine and chlorproguanil-dapsone treatment of Plasmodium falciparum malaria. J Infect Dis 2002; 185: 380-8.

[6] Djimde A, Doumbo OK, Steketee RW, Plowe CV. Application of molecular marker for surveillance of chloroquine- resistant $P$. falciparum malaria. Lancet 2001; 358: 890-1.

[7] Duraisingh MT, Curtis J, Warhurst DC. Plasmodium falciparum: detection of polymorphisms in the dihydrofolate reductase and dihydropteroate synthetase genes by PCR and restriction digestion. Exp Parasitol 1998; 89: 1-8.

[8] Muntaser EI, Falih MA, Ibrahim ME, Elrashid ME. A case of Plasmodium falciparum malaria sensitive to chloroquine but resistant to pyrimethamine/ sulphadoxine in Sennar Sudan. Trans Roy Soc Trop Med Hyg 1991; 81: 440.

[9] Elkheir HK, Elkarim EF, Eltayeb IB, Elkadaru AE, Babikir HA Ibrahim AM. Efficacy of Sulphadoxine and Pyrimethamine, Doxycycline and their combination in the treatment of chloroquine resistant falciparum malaria. Saudi Med J 2001; 22: 690-3.

[10] Abd EL, Wahed MO. Polymorphism of Pfcrt and Pfmdr-1 genes and chloroquine resistance Plasmodium falciparium in Central Sudan. M.Sc. thesis University of Gezira, Sudan, 2005.

[11] Fidock D, Nomura T, Talley A, et al. Mutations in the $P$ falciparum digestive vacuole transmembrane protein PfCRT and evidence for their role in chloroquine resistance. Mol Cell 2000; 6: 861-71.

[12] Khalil IF, Michael AF, Anita M, Ronn HA, Gabar TJ. e linexk, Gwiria MHS, IBC. Bygbierg. Pyrimethamine/ Sulfadoxine combination in the treatment of uncomplicated falciparum malaria: relation between DHPS/DHFR genotypes. Sulfadoxine plasma levels and treatment outcome. Am J Trop Med Hyg 2002; 67: 2259.

[13] Roper C, Pearce R, Bredenkamp B, et al. Antifolate antimalarial resistance in southeast Africa: a population-based analysis. Lancet 2003; 361: 1174-81.

Received: July 01, 2009

Revised: September 01, 2009

Accepted: September 06, 2009

(C) Omer et al.; Licensee Bentham Open.

This is an open access article licensed under the terms of the Creative Commons Attribution Non-Commercial License (http://creativecommons.org/licenses/bync/3.0/), which permits unrestricted, non-commercial use, distribution and reproduction in any medium, provided the work is properly cited. 